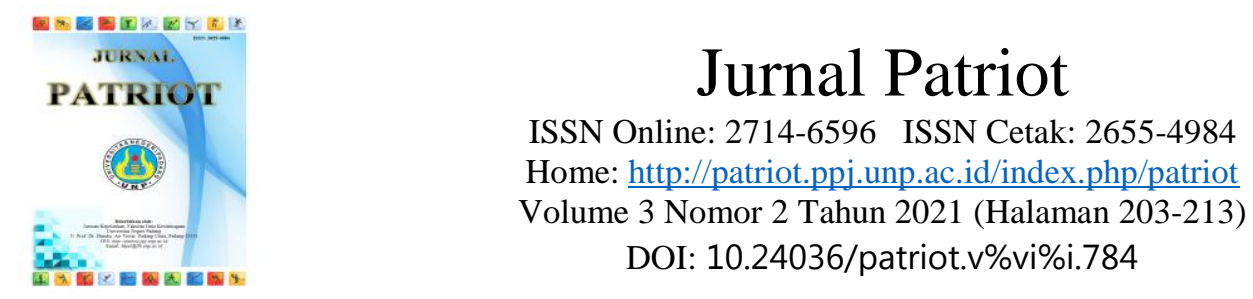

\title{
Tingkat Kepercayaan Diri dan Kecemasan Atlet PPLP Jawa Barat selama Menjalani Training From Home (TFH) pada Masa Adaptasi Kebiasaan Baru (AKB)
}

\author{
Ira Purnamasari ${ }^{1 *}$, Geraldi Novian ${ }^{2}$ \\ ${ }^{1}$ Program Studi Pendidikan Kepelatihan Olahraga, Fakultas Pendidikan Olahraga dan \\ Kesehatan, Universitas Pendidikan Indonesia, Indonesia \\ ${ }^{2}$ Program Studi Pendidikan Olahraga, Sekolah Pascasarjana, Universitas Pendidikan Indonesia, \\ Indonesia \\ Email Korespondensi: irapurnamasari@upi.edu
}

Informasi Artikel:

Dikirim: 20 Mei 2021 Direvisi: 15 Juli 2021 Diterbitkan: 19 Juli 2021

\begin{abstract}
ABSTRAK
Penelitian ini bertujuan untuk mengetahui tingkat kepercayaan diri dan kecemasan atlet PPLP Jawa Barat selama menjalani Training From Home (TFH) pada masa Adaptasi Kebiasaan Baru (AKB). Metode penelitian yang digunakan adalah metode deskriptif kuantitatif dengan correlational design. Subjek dalam penelitian ini adalah 32 atlet PPLP Jawa Barat yang terdiri dari 9 cabang olahraga dengan usia 16,218 $\pm 1,099$ tahun yang diambil menggunakan simple random sampling dari populasi. Instrumen penelitian yang digunakan berupa kuesioner kepercayaan diri dan Sport Anxiety Scale-2 (SAS-2). Pengisian kuesioner mengunakan skala Likert dan didistribusikan satu kali kepada subjek dengan menggunakan media Google Form pada bulan Maret 2021. Analisis data menggunakan SPSS versi 24 dengan melakukan deskripsi statistik, uji normalitas, uji korelasi dan persentase hasil. Berdasarkan hasil studi, maka dapat disimpulkan bahwa terdapat hubungan yang signifikan antara tingkat kepercayaan diri dan kecemasan atlet PPLP Jawa Barat selama menjalani TFH pada masa AKB. Atlet PPLP Jawa Barat memiliki tingkat kepercayaan diri yang tinggi $(61 \%)$ dan tingkat kecemasan yang rendah (38\%). Penulis menyarankan untuk lebih memperhatikan aspek psikologis dan jangan hanya berfokus pada aspek fisiologis atlet, terlebih pada situasi dan kondisi saat ini. Penulis menyarankan agar program latihan mental dapat diintegrasikan dalam periodisasi program latihan yang telah disusun.
\end{abstract}

Kata Kunci: kepercayaan diri; kecemasan; atlet pplp jawa barat; training from home; adaptasi kebiasaan baru

\section{Self-Confidence and Anxiety Level of West Java PPLP Athletes during Training From Home (TFH) in the New Habit Adaptation Period (AKB)}

ABSTRACT
This study aims to determine the level of confidence and anxiety of West Java PPLP athletes while undergoing Training From Home (TF) during the New Habit Adaptation (AKB) period. The research method used is a quantitative descriptive method with a correlational design. The subjects in this study were 32 West Java PPLP athletes consisting of 9 sports with ages $16.218 \pm 1.099$ years, taken using simple random sampling from the population. The research instrument used was a self-confidence questionnaire and the Sport Anxiety Scale-2 (SAS-2). Filling out the questionnaire using a Likert scale and distributing it once to subjects using Google Form media in March 2021. Data analysis using SPSS version 24 by performing statistical descriptions, normality test, correlation test, and percentage of results. Based on the results of the study, it can be concluded that there is a significant relationship between the level of confidence and anxiety of West Java PPLP athletes during TFH during the AKB period. 
West Java PPLP athletes have high levels of self-confidence (61\%) and low levels of anxiety (38\%). We suggests paying more attention to psychological aspects and not only focusing on the physiological aspects of athletes, especially on the current situation and condition. The author suggests that the psychological training program can be integrated in the periodization of the training program that has been prepared.

Keywords: self-confidence; anxiety; west java pplp athletes; training from home; new habit adaptation

\section{PENDAHULUAN}

Dunia saat ini masih mengalami pandemik COVID-19, berbagai usaha telah dilakukan oleh pemerintah maupun individu untuk mengurangi laju penyebaran virus COVID-19, seperti penerapan protokol kesehatan, penutupan objek vital, pembelajaran daring dan lain-lain. Namun, roda kehidupan harus terus berjalan sehingga pemerintah kembali mulai mengizinkan kembali masyarakat untuk melakukan aktivitas dengan berbagai ketentuan yang disebut dengan masa Adaptasi Kebiasaan Baru (AKB) (Sembiring et al., 2020). AKB juga berlaku dalam dunia olahraga dimana para pelaku olahraga menerapkan harus protokol kesehatan untuk melaksanakan aktivitas latihan (Purnamasari \& Febrianty, 2020). Selain itu, latihan dari rumah atau Training From Home (TFH) diberbagai tempat latihan juga diterapkan, termasuk di Pusat Pembinaan dan Latihan Olahraga Pelajar (PPLP) Jawa Barat. Hal ini dilakukan sebagai usaha yang ditempuh oleh para pembina dan pelatih PPLP untuk tetap menjaga kondisi fisik atlet di masa AKB.

Dalam kondisi normal, atlet PPLP Jawa Barat melakukan latihan secara terpusat di tempat yang disediakan, tetapi dalam situasi Pandemik COVID-19 yang masih berlangsung sampai dengan tulisan ini dibuat dan dalam keadaan yang memasuki masa Adaptasi Kebiasaan Baru (AKB), proses latihan harus dilakukan dari rumah atau Training From Home (TFH). Proses latihan harus tetap dilaksanakan karena atlet yang tergabung di PPLP Jawa Barat mempunyai tanggung jawab untuk berlatih dan tetap mempertahankan penampilan atau performa dengan tujuan agar tetap bisa menghasilkan prestasi terbaiknya. Dalam proses pelaksanaan $\mathrm{TFH}$, tentunya atlet mengalami berbagai kondisi yang mempengaruhi proses latihan, baik secara psikologis maupun fisiologis (Reiner et al., 2021; Wong et al., 2020), seperti sulit memahami program latihan yang berikan pelatih secara daring, minimnya sarana dan pra-sarana latihan, minimnya interaksi antara sesama atlet maupun pelatih, kekhawatiran akan adanya virus, lingkungan rumah yang kurang kondusif, dan lain sebagainya. Secara khusus, pada studi ini penulis menyoroti terkait aspek psikologis.

Aspek psikologis mempunyai peran penting dalam penampilan olahraga. Aspek psikologis ini seringkali diabaikan dalam proses latihan dan cenderung lebih banyak diperhatikan pada saat pertandingan (Komarudin, 2016a). Hal ini sangat disayangkan mengingat berbagai studi literatur telah menunjukkan bahwa penerapan strategi psikologis untuk meningkatkan performa dalam olahraga telah berkembang dan terbukti secara signifikan selama beberapa dekade terakhir (Abdullah et al., 2016). Aspek 
psikologis yang mempengaruhi penampilan olahraga sangat banyak, diantaranya: kepercayaan diri, motivasi berprestasi, intelegensi, kemandirian, agresivitas,semangat, rasa tanggung jawab, kecemasan dan sebagainya (Effendi, 2016). Namun, tidak semua atlet memiliki aspek psikologis yang baik dalam proses latihan. Dalam masa AKB, atlet cenderung mengalami perubahan secara psikologis. Perubahan secara psikologis pada atlet, seperti stress, sulit berkonsentrasi dan gangguan ketangguhan mental, sedangkan kita ketahui bahwa hal ini harus dimiliki atlet sehingga mampu menghadapi tantangan yang lebih berat pada saat akan menghadapi latihan maupun menghadapi pertandingan (Sukadiyanto, 2011).

Pada studi ini, penulis mengkaji aspek psikologis berupa kepercayaan diri dan kecemasan yang mana setiap atlet memiliki kondisi yang berbeda-beda (Dimyati et al., 2013). Kepercayaan diri merupakan salah satu faktor yang dianggap mempengaruhi performa olahraga (Beaumont et al., 2014). Kepercayaan diri adalah sikap positif atlet untuk mengembangkan nilai positif terhadap dirinya dan juga lingkungannya, seperti dalam lingkungan berlatih dan lingkungan bertanding. Pengertian lain mengenai kepercayaan diri adalah suatu perasaan yang berisi kekuatan, kemampuan dan keterampilan untuk melakukan atau menghasilkan sesuatu yang dilandasi keyakinan untuk sukses (Mirhan, 2016). Atlet yang memiliki kepercayaan diri yang baik akan memiliki keyakinan yang lebih kuat pada kemampuan dan pendapat mereka sendiri dan memungkinkan mereka untuk lebih efektif melakukan sesuatu sehingga mereka mampu mencapai kesuksesan. Penilaian positif terhadap diri sendiri mengenai kemampuan terhadap performa dirinya untuk menghadapi berbagai situasi dan tantangan serta kemampuan mental untuk mengurangi pengaruh negatif terhadap keragu-raguan yang mendorong atlet untuk meraih keberhasilan dan juga kesuksesan tanpa tergantung kepada pihak lain dan bertanggung jawab atas keputusan yang telah dipilihnya (Mirhan, 2016). Kepercayaan diri erat kaitannya dengan falsafah pemenuhan diri dan keyakinan diri. Atlet yang mempunyai rasa percaya diri yang baik percaya bahwa dirinya akan mampu memberikan penampilan yang sesuai dengan harapannya (Setiadarma, 2011).

Aspek psikologis yang berikutnya adalah kecemasan yang lazim dialami oleh atlet. Kecemasan merupakan unsur kejiwaan yang menggambarkan perasaan, keadaan emosional yang dimiliki oleh seseorang pada saat menghadapi kenyataan atau kejadian dalam hidupnya (Susanti \& Rasima, 2020). Kecemasan sering kali timbul ketika atlet tidak yakin atau takut dalam melakukan sesuatu yang berkaitan dengan performa. Kecemasan yang dihadapi oleh atlet dapat mempengaruhi penampilan dalam skala yang berbeda-beda dari setiap individu atlet. Kecemasan terbagi menjadi tiga tingkatan yaitu kecemasan ringan, sedang dan berat (Swadesi, 2011). Tingkatan kecemasan ini yang akan mempengaruhi penampilan atlet, apabila atlet memiliki kecemasan yang ringan makan penampilannya akan meningkat, tetapi apabila atlet memiliki kecemasan yang tinggi maka penampilan atlet akan menurun. Kepercayaan diri dan kecemasan dapat hadir kapanpun dan dimanapun bagi atlet, atlet yang tidak mampu melakukan 
manajemen kepercayaan diri dan kecemasan dengan baik, maka ia akan cenderung mengalami efek negatif. Ketika menjalani TFH pada masa AKB ini, kedua aspek psikologis ini harus benar-benar diperhatikan karena akan sangat mengkhawatirkan jika berlebihan dan tidak mampu diatur dengan baik. Atlet PPLP Jawa Barat yang masih tergolong junior secara usia biologis, memiliki potensi yang sangat besar untuk menorehkan prestasi, namun mereka masih belum memiliki kondisi psikologis yang stabil, terlebih dengan adanya pandemik COVID-19 ini. Maka, penulis merasa studi ini perlu dilakukan dengan tujuan untuk mengetahui hubungan antara tingkat kepercayaan diri dengan kecemasan atlet PPLP Jawa Barat selama menjalani Training From Home (TFH) pada masa Adaptasi Kebiasaan Baru (AKB).

\section{METODE}

Penelitian ini menggunakan metode deskriptif kuantitatif dengan correlational design (Fraenkel et al., 2012). Subjek dalam penelitian ini adalah 32 atlet PPLP Jawa Barat (14 putra dan 18 putri) yang terdiri dari 9 cabang olahraga (angkat besi, atletik, dayung, gulat, judo, karate, senam, taekwondo dan tarung derajat) dengan usia 16,218 \pm 1,099 tahun yang diambil menggunakan simple random sampling dari populasi. Subjek merupakan atlet berstatus pelajar (14 SMP dan 18 SMA) yang dibina khusus oleh Dinas Pemuda dan Olahraga (DISPORA) Jawa Barat. Penulis melihat bahwa atlet-atlet ini memiliki potensi besar untuk meraih prestasi, namun masih belum memiliki kondisi psikologis yang stabil karena sedang berada pada masa remaja yang merupakan periode perkembangan kepribadian yang sangat dinamis (Harris et al., 2016) dan perkembangannya dipengaruhi oleh faktor pematangan (misalnya: kognitif, sosial) dan lingkungan (misalnya: pelatih) (McCarthy et al., 2010), khususnya pada masa pandemik COVID-19 karena mereka menjalani latihan mandiri di rumah masing-masing.

Instrumen penelitian yang digunakan berupa kuesioner kepercayaan diri yang disusun oleh penulis dan Sport Anxiety Scale-2 (SAS-2) (Ramis et al., 2015). Pengisian kuesioner menggunakan skala Likert (Mawardi, 2019) dan telah melewati tahap uji validitas $(0,279)$ dan reliabilitas $(0,708)$ sehingga dapat digunakan untuk penelitian ini. Kuesioner didistribusikan satu kali kepada subjek dengan menggunakan media Google Form pada bulan Maret 2021. Adapun indikator kuesioner dapat dilihat pada Gambar 1.
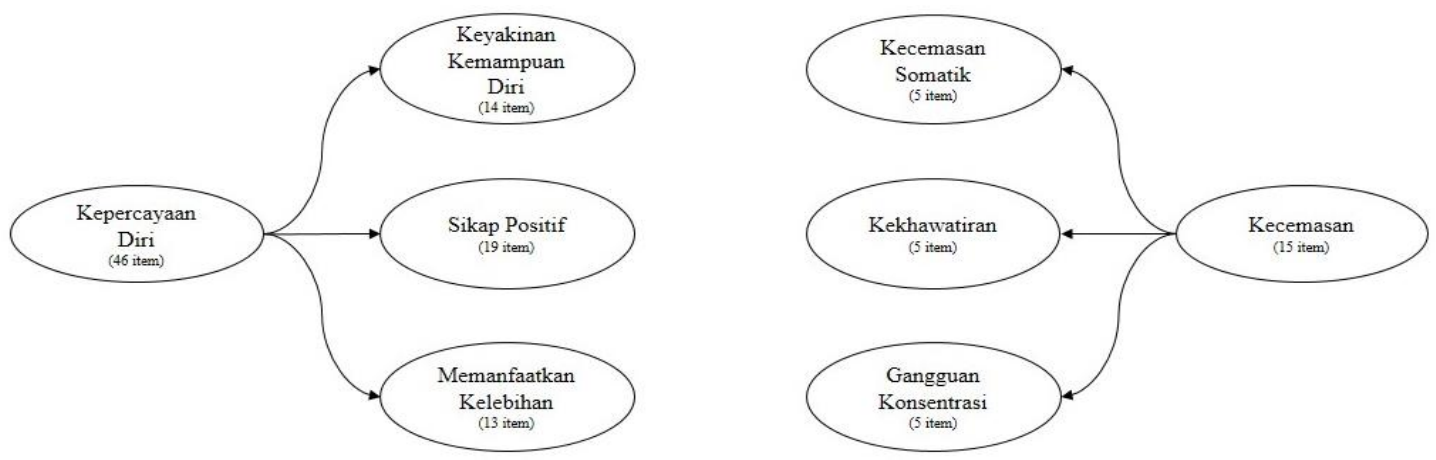

Gambar 1. Indikator Kuesioner 
Data yang diperoleh kemudian diolah dan dianalisis menggunakan bantuan software SPSS versi 24 dengan melakukan deskripsi statistik, uji normalitas, uji korelasi dan persentase hasil (Santoso, 2017).

\section{HASIL}

Hasil pengolahan dan analisis data disajikan dalam bentuk tabel dan gambar agar lebih mudah dipahami.

Tabel 1. Deskripsi Statistik

\begin{tabular}{ccccc}
\hline Variabel & Minimum & Maximum & Mean & Std. Deviation \\
\hline Kepercayaan Diri & 109 & 169 & 139,97 & 16,109 \\
Kecemasan & 15 & 50 & 28,69 & 9,461 \\
\hline$* N=32$ & & & &
\end{tabular}

Berdasarkan Tabel 1, diketahui bahwa variabel kepercayaan diri memiliki nilai terkecil sebesar 109, nilai terbesar sebesar 169, nilai rata-rata sebesar 139,97 dan nilai standar deviasi sebesar 16,109. Sedangkan variabel kecemasan memiliki nilai terkecil sebesar 15, nilai terbesar sebesar 50, nilai rata-rata 28,69 dan nilai standar deviasi sebesar 9,461. Kemudian penulis melakukan uji normalitas data, dapat dilihat pada Tabel 2.

Tabel 2. Uji Normalitas

\begin{tabular}{ccc}
\hline Variabel & Asymp. Sig. (2-tailed) & Keterangan \\
\hline Kepercayaan Diri & 0,200 & Normal \\
Kecemasan & 0,134 & Normal \\
\hline
\end{tabular}

Tabel 2 menunjukkan hasil uji normalitas data menggunakan teknik Kolmogorov-Smirnov Test. Variabel kepercayaan diri dan kecemasan memperoleh nilai Asymp. Sig. (2-tailed) >0,005, maka data dinyatakan berdistribusi normal sehingga penulis dapat menggunakan uji statistik parametrik.

Tabel 3. Uji Korelasi

\begin{tabular}{cccc}
\hline Variabel & Pearson Correlation & Sig. (2-tailed) & Keterangan \\
\hline $\begin{array}{c}\text { Kepercayaan Diri - } \\
\text { Kecemasan }\end{array}$ & 0,576 &, 001 & $\mathrm{H}_{0}$ diterima \\
\hline
\end{tabular}

Tabel 3 menunjukkan hasil uji korelasi data menggunakan teknik Bivariate Pearson Correlation. Berdasarkan hasil uji, diperoleh nilai Sig. (2-tailed) $<0,05$ maka $\mathrm{H}_{0}$ diterima. Sehingga penulis dapat menyimpulkan bahwa terdapat hubungan yang signifikan antara kepercayaan diri dengan kecemasan. 


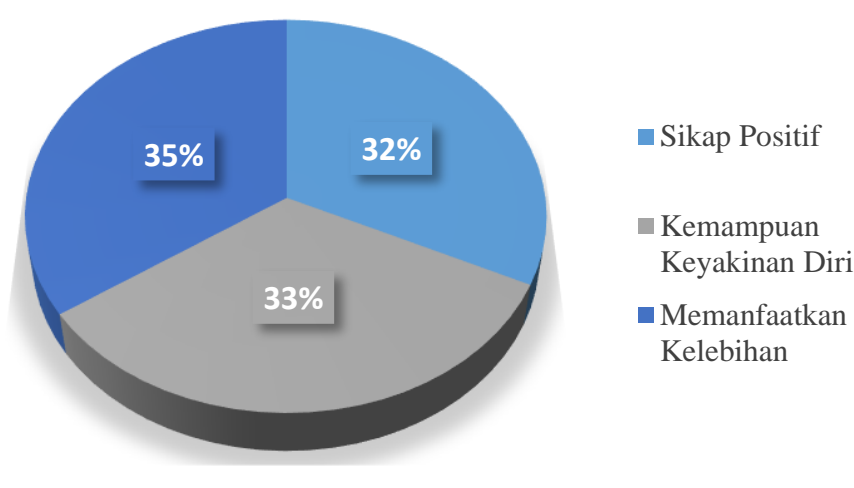

Gambar 2. Persentase Tingkat Kepercayaan Diri

Berdasarkan Gambar 2, diketahui bahwa kepercayaan diri atlet PPLP Jawa Barat memiliki persentase yang hampir sama pada setiap indikator, yaitu memanfaatkan kelebihan 35\%, kemampuan keyakinan diri 33\% dan sikap positif 32\%. Namun, secara keseluruhan atlet PPLP Jawa Barat memiliki persentase kepercayaan diri sebesar $61 \%$. Hal ini berarti bahwa selama menjalani TFH pada masa AKB, atlet PPLP Jawa Barat tetap memiliki tingkat kepercayaan diri yang tinggi.

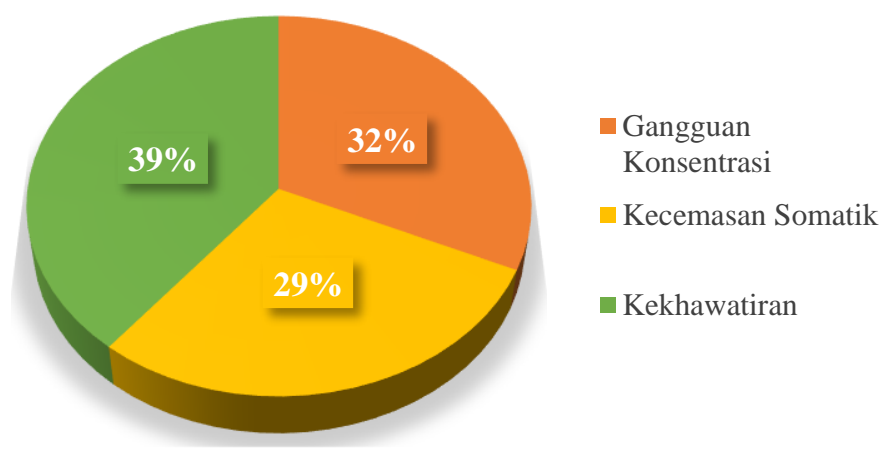

Gambar 3. Persentase Tingkat Kecemasan

Berdasarkan Gambar 3, diketahui bahwa kecemasan atlet PPLP Jawa Barat memiliki persentase yang berbeda pada setiap indikator, yaitu kekhawatiran $39 \%$, gangguan konsentrasi $32 \%$ dan kecemasan somatik 29\%. Namun, secara keseluruhan atlet PPLP Jawa Barat memiliki persentase kecemasan sebesar 38\%. Hal ini berarti bahwa selama menjalani TFH pada masa AKB, atlet PPLP Jawa Barat memiliki tingkat kecemasan yang rendah.

\section{PEMBAHASAN}

Prestasi atlet dihasilkan dari proses yang panjang, dari mulai latihan sebagai pemula sampai dengan menjadi atlet elite. Hal ini dihasilkan melalui proses pembinaan yang berkesinambungan. Oleh karena itu kehadiran PPLP adalah sebagai salah satu 
usaha pembinaan olahraga di Indonesia untuk dapat menghasilkan atlet elite(Jamalong, 2016). Terdapat empat aspek yang harus diperhatikan untuk menghasilkan prestasi atlet yaitu aspek teknik, taktik, fisik dan psikologis/mental (Harsono, 2017). Secara khusus, aspek psikologis yang dimiliki atlet dengan baik akan membantu meningkatkan performa dan memperbesar persentase ketercapaian prestasi (Chan \& Aziz, 2020; Subandi \& Sin, 2018; Syukriah \& Aziz, 2019). Penerapan aspek psikologis dalam latihan mengarah pada dua tujuan pokok, yaitu mempelajari bagaimana faktor-faktor psikologis dapat mempengaruhi penampilan fisik dan mempengaruhi secara positif perkembangan kesehatan dan kesempurnaan psikologis atlet tersebut. Hal ini memperlihatkan bahwa atlet memiliki kemampuan fisik yang baik namun tidak dengan memiliki faktor psikologis yang baik, maka kemampuan fisik yang dimilikinya akan menurun, seperti yang dikemukakan bahwa faktor kondisi fisik dan faktor psikologis saling mempengaruhi satu dengan yang lainnya (Firmansyah, 2017). Oleh karena itu, aspek psikologis memiliki pengaruh besar dalam proses penampilan dari atlet.

Dalam studi ini didapatkan hasil bahwa setelah melakukan latihan dengan metode TFH, tingkat kepercayaan diri atlet PPLP berada pada kategori baik dengan presentase sebesar $61 \%$. Salah satu faktor yang membuat percaya diri para atlet PPLP baik adalah sikap disiplin yang biasa ditanamkan oleh pelatih (Candra, 2016) pada saat mereka melakukan latihan di situasi latihan tanpa adanya pandemik COVID-19, sehingga para atlet sudah mempunyai dasar untuk bertanggung jawab melakukan latihan walaupun tanpa didampingi oleh pelatih. Seorang atlet yang memiliki rasa percaya diri yang baik, percaya bahwa dirinya akan mampu menampilkan kinerja olahraga seperti yang diharapkan (Yulianto \& Nashori, 2006). Proses untuk menjadikan seorang atlet menjadi potensial dibutuhkan melalui proses pembinaaan yang efektif (Komarudin, 2016b). Walaupun dimasa AKB ini para atlet dipaksa untuk berlatih sendiri di daerahnya, para atlet melakukan latihan dengan penuh tanggung jawab dan mempunyai motivasi untuk menang dan berprestasi (Leyton-Román et al., 2021; Rahayuni, 2020).

Atlet PPLP Jawa Barat melakukan latihan sesuai dengan instruksi dari pelatih, bahwa latihan dilaksanakan dari rumah masing masing dengan memperhatikan protokol Kesehatan agar tidak tertular dari virus COVID-19. Hal lain yang jadi pilihan para atlet untuk melaksanakan latihan walaupun dalam situasi yang sulit adalah dengan adanya prinsip detraining, dimana efek latihan akan hilang apabila tidak dilatih secara intensif (Jagim et al., 2020; Jukic et al., 2020). Aspek psikologis lain yang dikaji dalam penelitian ini adalah kecemasan. Pada masa AKB ini banyak orang menghadapi kecemasan (Cao et al., 2020). Hasil lain dari studi ini adalah atlet PPLP Jawa barat memiliki tingkat kecemasan yang rendah dengan persentase sebesar 38\%, hal ini sangat baik, karena atlet yang memiliki kecemasan yang tinggi akan mempengaruhi performanya (Kleine, 1990), begitu pula sebaliknya, apabila atlet memiliki kecemasan yang rendah maka performanya akan baik. Pelatih berharap bahwa atlet memiliki 
kecemasan yang rendah, sehingga pada saat pertandingan akan menghasilkan performa yang baik dan diharapkan mendapatkan prestasi yang tinggi.

Meskipun tingkat kecemasan atlet PPLP Jawa Barat pada masa AKB tergolong rendah, namun tetap harus diperhatikan karena tetap bisa berdampak pada banyak hal. Kecemasan yang dimiliki oleh atlet PPLP pada masa pandemik COVID-19 ini bisa disebabkan oleh banyak hal, seperti: tidak terjadinya interaksi langsung ketika latihan, karantina mandiri dirumah, kekhawatiran akan performanya, target yang dicanangkan pelatih, dan lain-lain. Atlet harus mampu mengatasi kecemasan ini agar tidak mengganggu performanya, namun tidak bisa dipungkiri bahwa pandemik COVID-19 ini menjadi tantangan baru, khususnya dalam olahraga. Kita harus mampu beradaptasi dengan situasi dan kondisi saat ini, seperti yang disampaikan oleh pemerintah, yaitu Adaptasi Kebiasaan Baru (AKB), beradaptasi dengan situasi dan kondisi saat ini dengan mengubah kebiasaan lama menjadi kebiasaan baru. Atlet akan dibayang-bayangi rasa takut akan kegagalan dan cenderung akan merugikan diri sendiri, bahkan tidak jarang atlet tidak mau lagi mengikuti latihan atau pertandingan (Moen et al., 2017). Kecemasan yang dialami atlet PPLP Jawa Barat merupakan hal yang wajar terjadi mengingat mereka tetap berusaha berlatih meski dalam situasi yang 'tidak mendukung' sepenuhnya. Kecemasan juga dapat menjadi mekanisme pertahanan diri terhadap ancaman dari luar.

Berdasarkan hasil uji korelasi, diperoleh hasil bahwa terdapat hubungan yang signifikan antara tingkat kepercayaan diri dan kecemasan atlet PPLP Jawa Barat selama menjalani TFH pada masa AKB, sehingga hipotesa penulis terbukti. Hasil ini juga sejalan dengan hasil penelitian terdahulu yang mengemukakan bahwa terdapat hubungan hubungan yang signifikan antara kecemasan dan kepercayaan diri atlet (Wijaya, 2018). Kepercayaan diri dan kecemasan atlet PPLP Jawa Barat khususnya pada masa AKB ini saling berkaitan dan tidak dapat diabaikan satu sama lainnya. Semakin tinggi tingkat kepercayaan diri atlet, maka atlet akan memiliki tingkat kecemasan yang semakin rendah, begitu pula sebaliknya. Tingkat kepercayaan diri yang tinggi juga tidak menjamin akan menampilkan performa terbaiknya dan tingkat kecemasan yang rendah juga tidak menjadi atlet akan menampilkan performa yang buruk. Maka, sangat diperlukan adanya perhatian khusus berupa analisa kondisi tersebut pada atlet, khususnya atlet PPLP Jawa Barat agar dapat ditangani dan diatur dengan sebagaimana mestinya. Karena kita ketahui bersama bahwa prestasi atlet merupakan hasil akumulatif dari berbagai aspek, khususnya aspek psikologis (Novian \& Noors, 2020). Hal ini harus menjadi perhatian khusus bagi atlet maupun pelatih agar proses pencapaian prestasi atlet tetap bisa terlaksana dengan baik walaupun menjalani TFH dalam masa AKB akibat pandemik COVID-19. Di masa mendatang, pengurus, pembina maupun pelatih harus memiliki persiapan jika terjadi situasi dan kondisi yang seperti ini untuk menghindari atau meminimalkan gangguan yang signifikan dalam pelatihan (Jagim et al., 2020). 


\section{KESIMPULAN}

Berdasarkan hasil studi, maka dapat disimpulkan bahwa terdapat hubungan yang signifikan antara tingkat kepercayaan diri dan kecemasan atlet PPLP Jawa Barat selama menjalani TFH pada masa AKB. Atlet PPLP Jawa Barat memiliki tingkat kepercayaan diri yang tinggi dan tingkat kecemasan yang rendah. Hal ini sangat baik mengingat situasi dan kondisi yang berbeda dari biasanya. Salah satu faktor yang mempengaruhi hasil dari studi ini adalah sikap disiplin yang ditanamkan oleh para pembina dan pelatih PPLP Jawa Barat, sehingga atlet tetap melaksanakan program latihan TFH pada masa AKB. Penulis menyarankan kepada pengurus, pembina dan pelatih untuk lebih memperhatikan aspek psikologis atlet dan jangan hanya berfokus pada aspek fisiologis atlet, terlebih pada situasi dan kondisi saat ini. Penulis menyarankan agar program latihan mental dapat diintegrasikan dalam periodisasi program latihan yang telah disusun. Studi ini memiliki keterbatasan dalam jumlah sampel, sehingga penulis menyarankan untuk mengkaji topik serupa dengan lingkup atlet yang lebih luas.

\section{DAFTAR PUSTAKA}

Abdullah, M. R., Musa, R. M., Maliki, A. B. H. M. B., Kosni, N. A., \& Suppiah, P. K. (2016). Role of psychological factors on the performance of elite soccer players. Journal of Physical Education and Sport, 16(1), 170-176. https://doi.org/10.7752/jpes.2016.01027

Beaumont, C., Maynard, I. W., \& Butt, J. (2014). Effective Ways to Develop and Maintain Robust Sport-Confidence: Strategies Advocated by Sport Psychology Consultants. Journal of Applied Sport Psychology, 27(3), 301-318. https://doi.org/10.1080/10413200.2014.996302

Candra, A. R. D. (2016). Pembinaan Prestasi di Pusat Pendidikan dan Latihan Olahraga Pelajar (PPLP) Provinsi Jawa Tengah. ACTIVE, 5(2).

Cao, W., Ziwei, F., Guoqiang, H., Mei, H., Xinrong, X., Jiaxin, D., \& Jianzhong, Z. (2020). The psychological impact of the COVID-19 epidemic on college students in China. Psychiatry Research, 287(March 20, 2020), 1-5. http://www.embase.com/search/results? subaction=viewrecord \&from=export\&id=L 2005406993\%0Ahttp://dx.doi.org/10.1016/j.psychres.2020.112934

Chan, F. R., \& Aziz, I. (2020). Motivasi Atlet Pencak Silat Pusat Pendidikan Latihan Pelajar (PPLP). Jurnal Patriot, 2(1), 120-128. https://doi.org/https://doi.org/10.24036/patriot.v2i1.619

Dimyati, Herwin, \& Hastuti, T. A. (2013). Karakteristik Psikologis Atlet di Pusat 
Pendidikan dan Latihan Pelajar (PPLP). Jurnal Psikologi, 40(2), 143-158. https://doi.org/10.22146/jpsi.6973

Effendi, H. (2016). Peranan psikologi olahraga dalam meningkatkan prestasi atlet. Nusantara (Jurnal Ilmu Pengetahuan Sosial), 1, 23-30.

Firmansyah, H. (2017). HUBUNGAN ANTARA ASPEK FISIK DAN PSIKOLOGIS STUDI PADA ATLET SENAM ARTISTIK PUTRA JAWA BARAT. HUMANITAS, 14(1), 78-89.

Fraenkel, J. R., Wallen, N. E., \& Hyun, H. H. (2012). How to Design and Evaluate Research in Education (8th Ed.). Mc Graw Hill.

Harris, M. A., Brett, C. E., Johnson, W., \& Deary, I. J. (2016). Personality stability from age 14 to age 77 years. Psychology and Aging, 31(8), 862-874. https://doi.org/10.1037/pag0000133

Harsono. (2017). Kepelatihan Olahraga: Teori dan Metodologi. Bandung: PT. Remaja Rosdakarya.

Jagim, A. R., Luedke, J., Fitzpatrick, A., Winkelman, G., Erickson, J. L., Askow, A. T., \& Camic, C. L. (2020). The Impact of COVID-19-Related Shutdown Measures on the Training Habits and Perceptions of Athletes in the United States: A Brief Research Report. Frontiers in Sports and Active Living, 2(December), 1-6. https://doi.org/10.3389/fspor.2020.623068

Jamalong, A. (2016). Peningkatan prestasi olahraga nasional secara dini melalui pusat pembinaan dan latihan pelajar (PPLP) dan pusat pembinaan dan latihan mahasiswa (PPLM). Jurnal Pendidikan Olah Raga, 3(2), 156-168.

Jukic, I., Calleja-González, J., Cos, F., Cuzzolin, F., Olmo, J., Terrados, N., Njaradi, N., Sassi, R., Requena, B., Milanovic, L., Krakan, I., Chatzichristos, K., \& Alcaraz, P. E. (2020). Strategies and Solutions for Team Sports Athletes in Isolation due to COVID-19. Sports, 8(4), 56. https://doi.org/10.3390/sports8040056

Kleine, D. (1990). Anxiety and sport performance: A meta-analysis. Anxiety Research, 2(2), 113-131. https://doi.org/10.1080/08917779008249330

Komarudin. (2016a). Psikologi Olahraga. Bandung: PT. Remaja Rosdakarya.

Komarudin, H. S. (2016b). PROFIL PEMBINAAN ATLET POTENSIAL KONI KOTA BANDUNG (Upaya Menjaring Data Calon Atlet Potensial untuk Persiapan Porda XIII di Kabupaten Bogor). Jurnal Kepelatihan Olahraga, 8(2), 11-24. 
Leyton-Román, M., de la Vega, R., \& Jiménez-Castuera, R. (2021). Motivation and Commitment to Sports Practice During the Lockdown Caused by Covid-19. Frontiers in Psychology, 11, 3846. https://doi.org/10.3389/fpsyg.2020.622595

Mawardi, M. (2019). The Direction Of The Likert Attitude Scale Formulation To Measure Student's Attitude. Scholaria: Jurnal Pendidikan Dan Kebudayaan, 9(3), 292-304. https://doi.org/10.24246/j.js.2019.v9.i3.p292-304

McCarthy, P. J., Jones, M. V., Harwood, C. G., \& Olivier, S. (2010). What do young athletes implicitly understand about psychological skills? Journal of Clinical Sport Psychology, 4(2), 158-172. https://doi.org/10.1123/jcsp.4.2.158

Mirhan, J. B. K. J. (2016). HUBUNGAN ANTARA PERCAYA DIRI DAN KERJA KERAS DALAM OLAHRAGA DAN KETERAMPILAN HIDUP. Jurnal Olahraga Prestasi, 12(1), 86-96.

Moen, F., Myhre, K., Klöckner, C. A., Gausen, K., \& Sandbakk, Ø. (2017). Physical , Affective and Psychological determinants of Athlete Burnout. The Sport, 1-22.

Novian, G., \& Noors, I. P. M. (2020). Hubungan Gaya Kepemimpinan Pelatih dengan Prestasi Atlet Taekwondo. Gladi: Jurnal Ilmu Keolahragaan, 11(02), 151-164. https://doi.org/https://doi.org/10.21009/GJIK.112.07

Purnamasari, I., \& Febrianty, M. F. (2020). Adaptasi Latihan Judo Di Masa Pandemi Covid-19. In JURNAL PENJAKORA (Vol. 7, Issue 2). https://doi.org/10.23887/PENJAKORA.V7I2.27544

Rahayuni, K. (2020). Kesehatan Mental Atlet Indonesia saat Pandemi COVID-19: Tantangan, Rekomendasi dan Peluang Riset. Jurnal Sains Keolahragaan Dan Kesehatan, 5(2), 105-121. https://doi.org/10.5614/jskk.2020.5.2.5

Ramis, Y., Viladrich, C., Sousa, C., \& Jannes, C. (2015). Exploring the factorial structure of the sport anxiety scale-2: Invariance across language, gender, age and type of sport. Psicothema, 27(2), 174-181. https://doi.org/10.7334/psicothema2014.263

Reiner, S. L., Smith, G. H., \& Davis, R. B. (2021). Exercise participation and subjective well-being of collegiate athletes during COVID-19 Pandemic. Journal of Human Sport and Exercise, 17(3), 1-12. https://doi.org/10.14198/jhse.2022.173.16

Santoso, S. (2017). Complete Guide to Mastering Statistics with SPSS 24. Jakarta: PT. Elex Media Komputindo.

Sembiring, Br, E., \& Lim, P. (2020). EDUKASI ADAPTASI KEBIASAAN BARU DI 
LINGKUNGAN KAMPUS. JOURNAL OF DIGITAL EDUCATION, COMMUNICATION, AND ARTS (DECA), 3(2), 61-67.

Setiadarma M P. (2011). Dasar-dasar Psikologi Olahraga. Jakarta: Pustaka Sinar Harapan.

Subandi, R., \& Sin, T. H. (2018). Hubungan Antara Kecemasan (Anxiety) dan Koordinasi Mata Kaki Terhadap Shooting Pemain Sepakbola. Jurnal Patriot, 234239. https://doi.org/https://doi.org/10.24036/patriot.v0i0.37

Sukadiyanto. (2011). Pengantar Teori dan Metodologi Melatih Fisik. Bandung: CV. Lubuk Agung.

Susanti, \& Rasima. (2020). Hubungan tingkat kecemasan dengan kualitas tidur pada penderita hipertensi di UPT puskesmas Cot Seumeureung Kecamatan Samatiga Kabupaten Aceh Barat Tahun 2019. Jurnal Pendidikan, Sains, Dan Humaniora, 8(3), 387-396.

Swadesi, I. K. lwan. (2011). Hubungan Kecemasan Dan Agresivitas Atlet Terhadap Prestasi Olahraga Kabupaten Buleleng Dalam PORPROV Bali 2011. Journal Olahraga Prestasi, 11(1), 1-12. https://doi.org/https://doi.org/10.21831/jorpres.v11i1.10253

Syukriah, U., \& Aziz, I. (2019). Motivasi Atlet Dalam Mengikuti Kegiatan Pencak Silat. Jurnal Patriot, 1(3), 963-974. https://doi.org/https://doi.org/10.24036/patriot.v1i3.441

Wijaya, I. M. K. (2018). Kecemasan, Percaya Diri dan Motivasi Berprestasi Atlet UKM Bulutangkis. Penjakora, 5(1).

Wong, A. Y. Y., Ling, S. K. K., Louie, L. H. T., Law, G. Y. K., So, R. C. H., Lee, D. C. W., Yau, F. C. F., \& Yung, P. S. H. (2020). Impact of the COVID-19 pandemic on sports and exercise. Asia-Pacific Journal of Sports Medicine, Arthroscopy, Rehabilitation and Technology, 22, 39-44. https://doi.org/10.1016/j.asmart.2020.07.006

Yulianto, F., \& Nashori, F. (2006). Kepercayaan Diri Dan Prestasi Atlet Tae Kwon Do Daerah Istimewa Yogyakarta. Jurnal Psikologi Universitas Diponegoro, 3(1), 5562. https://doi.org/10.14710/jpu.3.1.55 